\title{
INTERNATIONAL HIGH-SKILLED PROFESSIONALS MIGRATION: FACTORS, DYNAMICS, PROSPECTS
}

\author{
Oleg Tolstoguzov \\ Maria Pitukhina
}

\author{
Russian Academy of Sciences, Petrozavodsk, Russia
}

Nowadays science has become a direct productive force. Structural changes in the knowledge production world system as well as in knowledge economy geography are widely shown. Capital is being slowly being shifted towards periphery, while its surplus (investment part) is transferred to other countries (where capital conditions are more attractive), thus leading to science funding increase in the countries that are already innovative leaders. Capital is always followed by intellectuals, highly skilled professionals, and academic degree holders. At the same time, a new type of economy development is possible due to human capital quality increase, in particular, thanks to knowledge concentration and science financing increase. In order to ensure knowledge concentration it is necessary to stimulate innovation activity, to regulate knowledge flows and brain migration, to develop the institutions that stimulate innovations and reduce agents' discrimination, to develop research

\section{Oleg Tolstoguzov}

Doctor of Economics and Researcher leader at the Institute of Economics at Karelian centre of Russian Academy of Sciences, Professor at the Institute of Economics and Law at Petrozavodsk State University, Republic of Karelia, Russia. Most of Tolstogusov's studies are dedicated to spatial and regional economy, state and municipal management, strategic planning of regions and cities, competitive law, entrepreneurship development and support. He is the research director of state projects dealing with territories' strategic and investment planning and development. He is the author of 7 books and more than 100 papers on economic analysis, regional policy and strategic planning.

E-mail: maria.pitukhina@gmail.com

\section{Maria Pitukhina}

Doctor of Political Science and a Researcher leader at Budget monitoring center at Petrozavodsk State University, Professor at the Department of International Relations and Political Science at Petrozavodsk State University, Researcher leader at the Institute of Economy at Karelian brunch of the Russian Science Academy, Petrozavodsk, Republic of Karelia, Russia. Pitukhina's publications appeared in such renown journals as: Russian Economic Development, Socis, Advanced Science Letters, World Economy and International Relations, International Journal of Ecological Economics and Statistics, International journal of ecology and development. She is also the author of 3 books on migration policy.

In 2006 Maria Pitukhina received a silver medal from the Ministry of Education and Science of Russia. Later she was a postdoctoral fellow at Bologna University (August 2010 - June 2011). She defended her Doctoral thesis in Political Science at St.Petersburg State University.

E-mail: maria.pitukhina@gmail.com 
schools, pursue a sustainable state innovative policy, modernize education processes. In the context of innovative economy and growing market competition both state's role and state responsibilities have strengthened.

Keywords: knowledge economy; highly skilled professionals; brain migration; publication activity; patent activity; academic degree holders' performance

\section{Introduction}

Contemporary global world has become more permeable, flows' mobility have increased, subjects interdependence has also increased together with the range of economic activities. A significant contributing factor in this regards has been the growing popularity of telecommunications and networks' development. The services sector expansion (through the development of intellectual, financial, information and communication technologies) has also contributed to the emergence of a new economic reality which is known now as "knowledge economy".

According to the Analytical Report of the Federation Council of the Federal Assembly of the Russian Federation, 25\% of the workforce is currently engaged in the field of science and high technologies in developed countries (Almaev et al., 2005). In the US 8\% of the population creates over $20 \%$ of the GDP as the country covers about $40 \%$ of the total global expenditures on research and development, while $66 \%$ of those present at the labour market have higher or incomplete higher education.

Therefore, the purpose of this research is to identify knowledge economy geography as well as to assess mobility factors of academic degree holders.

\section{Methodology}

"Geospatial paradigm" definition has been proposed by Alaev (1983). At the same time, our approach is not abandoning Shumpeter's evolutionary paradigm representing a qualitatively new technological order as a fundamental factor for global changes all over the world. We propose a geoeconomic invariant here - a system of empirically measured factors reflecting the relationship structure, relatively unchanged in both temporal and spatial dimensions of geographic objects. Our attention here focuses on spatial effects and space synergy factors' identification.

Our study stems from economic theory, new institutional and spatial economics, strategic management together with a wide range of analytical tools application. The main research method is the systematic approach which allows geographical objects' representation as an integrated complex system characterized by a set of economic processes (formed on knowledge and information platforms) as well as behavior patterns' variability (as responses to geoeconomic competition). At the same time, economy is seen here as an institutionalized process.

Within the framework of a proposed approach, brain concentration characterizing science and determining economic space synergy is considered. We estimate knowledge economy mainly "at the entrance point", similar to the approach proposed by Makarov (2003). However, we also evaluate the intellectual potential indicators determining knowledge production nature and its direction.

Our main data sources have been the "UNESCO Report on Science: on the way to 


\section{INTERNATIONAL HIGH-SKILLED PROFESSIONALS}

2030" (UNESCO, 2015),Rosstat data and various research publications on the topic. Since we are interested in geoeconomic strategies, the analysis was made based upon a long-term strategic choice of geoeconomic development vector. The time interval selected for characterizing the intellectual potential is 2007-2014.

\section{Factors Influencing Brain Migration}

The following factors could be pointed out as defining ones in relation to scientists' high mobility reasons in the world:

- standards of living, institutional and social standards affecting living conditions in donor states and recipient states (the traditional migration factor);

- state policy aimed at new technological development leading to investment growth in science and technologies (Arkhipov et al., 2018);

- establishing transboundary knowledge flows (researchers' mobility, international coauthorship, the right for co-ownership on inventions and so on);

- decline in qualification standards (e.g., growing number of scientific fraud cases, lesser value of academic and scientific degrees, other factors negatively affecting academic degree holders' quality.

According to the "UNESCO Science Report: towards 2030 - Executive Summary 2015", the following global trends can be called observable: investment growth in science and technology; increased number of significant international scientific projects as well as scientific publications and patents; and scientists' higher mobility. This demonstrates a stable tendency for a sharp increase in researchers' quantity.

There are $7.8 \mathrm{mln}$ researchers worldwide, and this number has risen by $21 \%$ since 2007. Most of them are located in the EU, China and the USA. In 2013 there were 440,600 scientists in Russia, their global share in scientists' articles publishing has fallen from 7.3\% to $5.7 \%$ since 2007 . At the world level, scientific publications' share has grown by $28 \%$ as compared to 2008 data. In $20141.27 \mathrm{mln}$ articles were published, the USA and the EU are leading in this field too.

Figure 1 shows changes in researchers' quantity in different countries during the period of 2007-2013. Figure 1 also shows significant increases in researchers' numbers as well as their concentration in the clusters of high-income countries and countries with the incomes above average. 


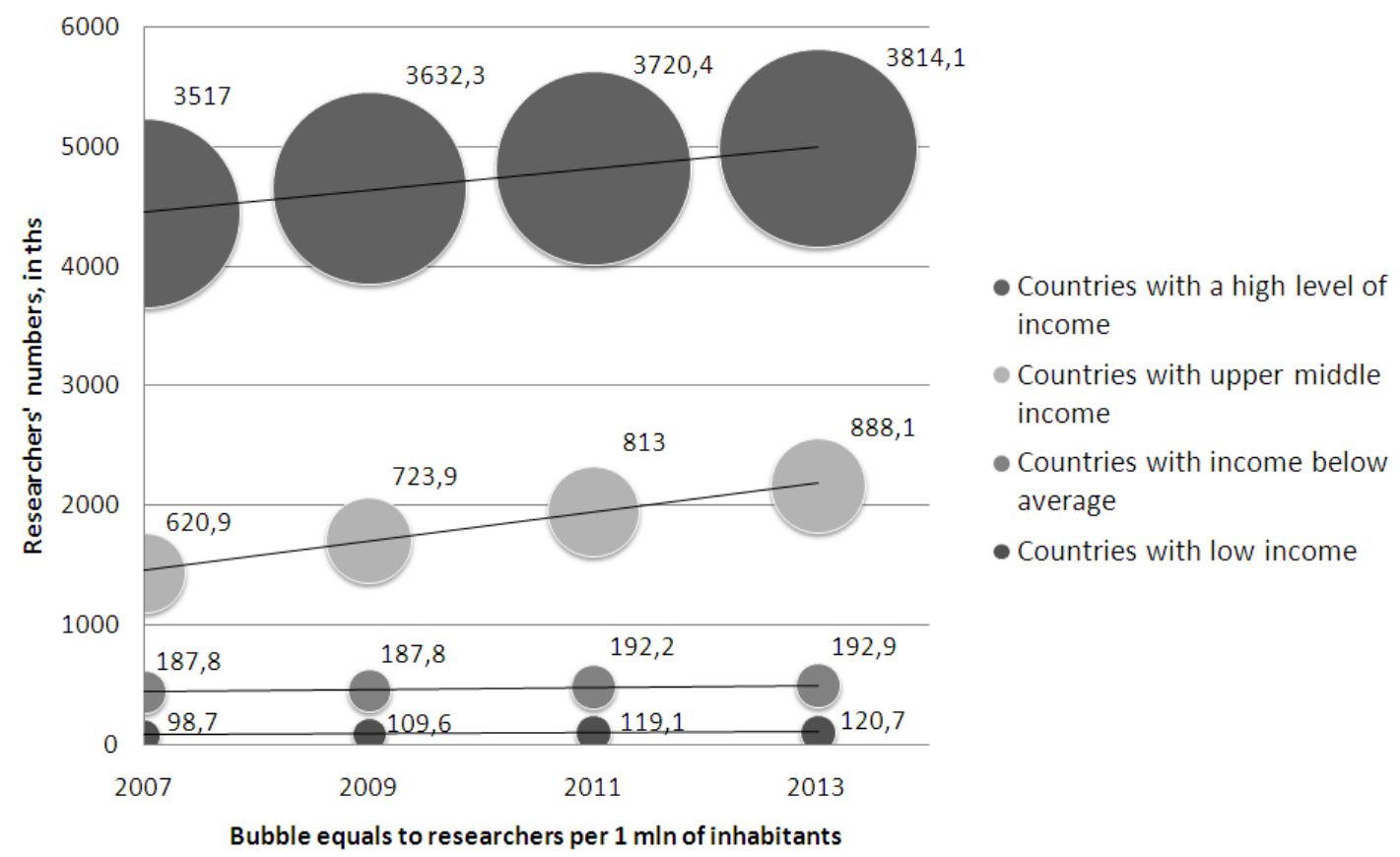

Figure 1 - Trends in researchers' concentration by clusters of countries during the period of 2007-2013

(Sources: UNESCO, 2015)

Figure 2 shows changes in the number of researchers in the selected countries during the period from 2007 to 2013.

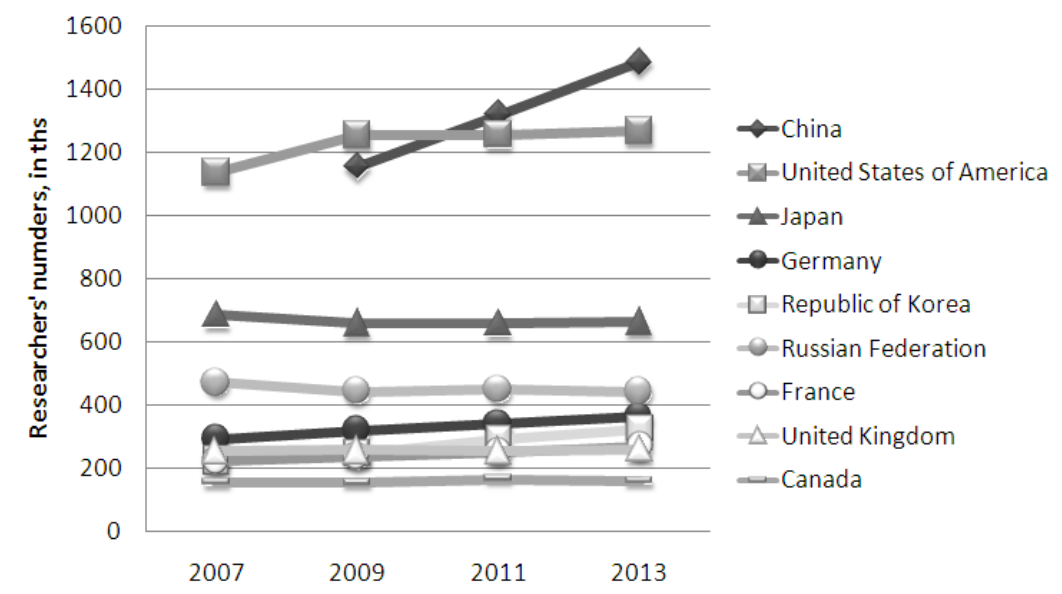

Figure 2 - Changes in the number of researchers in the selected countries of the world, 2007-2013

(Sources: UNESCO, 2015)

Intellectual potential concentration taking into account academic degree holders' skills predetermines the development of both innovative economy and knowledge economy. It is also characterized by the growth of financing in both production and commercialization of knowledge (the R\&D share in total expenditures of state and private enterprises), increase in 


\section{INTERNATIONAL HIGH-SKILLED PROFESSIONALS}

intellectual capital costs (patents to be registered, effective system of enterprises and markets).

Figure 3 shows some of the changes in this regard over the period of 2011-2013. Countries' intellectual potential concentration (grouped by the levels of countries' incomes) is measured through researchers' numbers and $\mathrm{R} \& \mathrm{D}$ funding per one researcher.

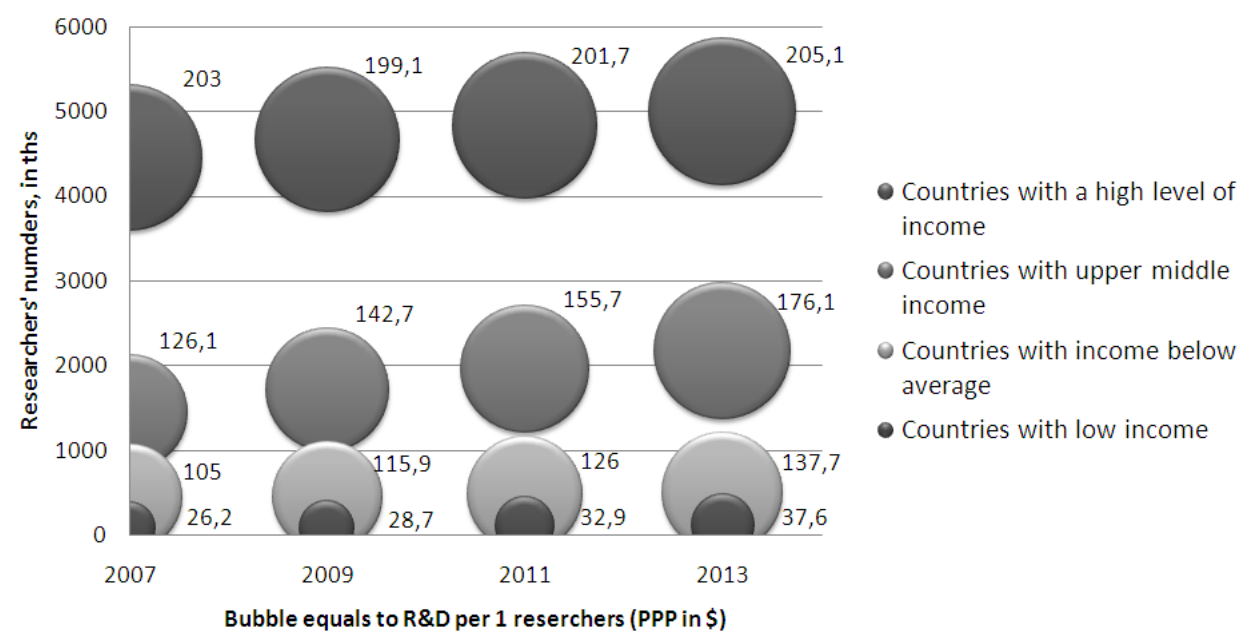

Figure 3 - Dynamics in researchers' numbers and R\&D financing per one researcher (PPP in ths USD)

(Sources: UNESCO, 2015)

It would be also prudent to compare the research and development (R\&D) expenditures of the most innovative countries' with the level of their economic development (see Table 1).

Table 1 - GDP per capita and R\&D expenditures, as of 2013

(UNESCO, 2015)

\begin{tabular}{|l|c|c|}
\hline \multicolumn{1}{|c|}{ Country } & $\begin{array}{c}\text { GDP per capita } \\
(2013)\end{array}$ & $\begin{array}{c}\text { R\&D expenditures share } \\
\text { in GDP, } \%(2013)\end{array}$ \\
\hline Norway & 64,406 & $2.85 \%$ \\
\hline USA & 53,042 & $2.81 \%$ \\
\hline Sweden & 44,658 & $3.30 \%$ \\
\hline Germany & 43,884 & $2.25 \%$ \\
\hline Denmark & 43,782 & $3.06 \%$ \\
\hline Finland & 39,740 & $3.32 \%$ \\
\hline Japan & 36,223 & $3.47 \%$ \\
\hline Italy & 35,281 & $1.25 \%$ \\
\hline The EU (av.) & 33,052 & $2.3 \%$ \\
\hline Russia & 25,248 & $1.12 \%$ \\
\hline Iran & 15,590 & $0.31 \%$ \\
\hline Georgia & 7,160 & $0.13 \%$ \\
\hline
\end{tabular}


R\&D expenditures per capita allow us track various actors' positions in the international dimension. Tab. 1 shows that the biggest R\&D expenditures (in percentage of GDP) are in Japan, France and Sweden.

The connection between GDP and investments in R\&D stimulates export growth through high technologies' implementation and scientific industries' development. Figure 4 shows how countries grouped according to their shares in the world GDP correlate with the group division according to their shares in the global R\&D.

During the period of 2007-2013, the leading countries were the United States, China and Japan, all three increased their R\&D funding rather seriously. The rest of the selected countries failed to keep up the pace set by the leaders.

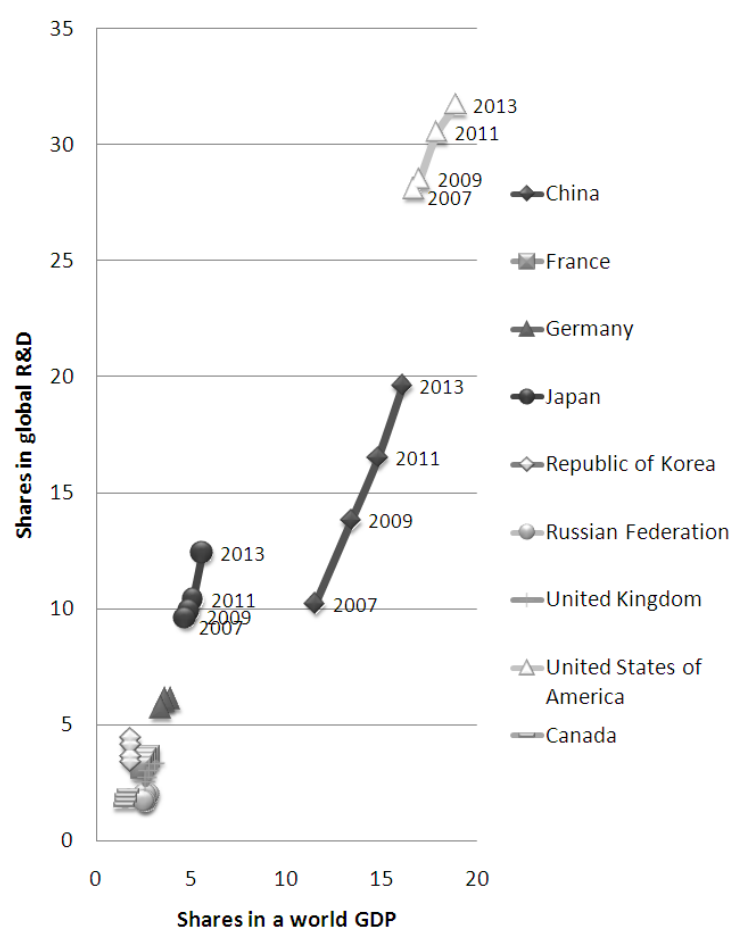

Figure 4 - Correlation between shares in the world GDP and shares in global R\&D

(Source: UNESCO, 2015)

According to the UNESCO Science Report, the growth in R\&D investments has been $31 \%$ between 2007 and 2013 (higher than the 20\% growth of the global GDP). The leading countries were the USA (28\% growth), China (20\% growth) and Japan (10\% growth). Russia had only $1.7 \%$ growth (Tran Van et al., 2017).

The EU, the USA and China, which are the leading actors in both global economics and global politics, have all recently announced creation of a new type of economy as their top priority.

Figure 5 shows the changes in R\&D expenditures per one researcher, which obviously assumes the appropriate quality of their workplaces and other work-related conditions. 


\section{INTERNATIONAL HIGH-SKILLED PROFESSIONALS}

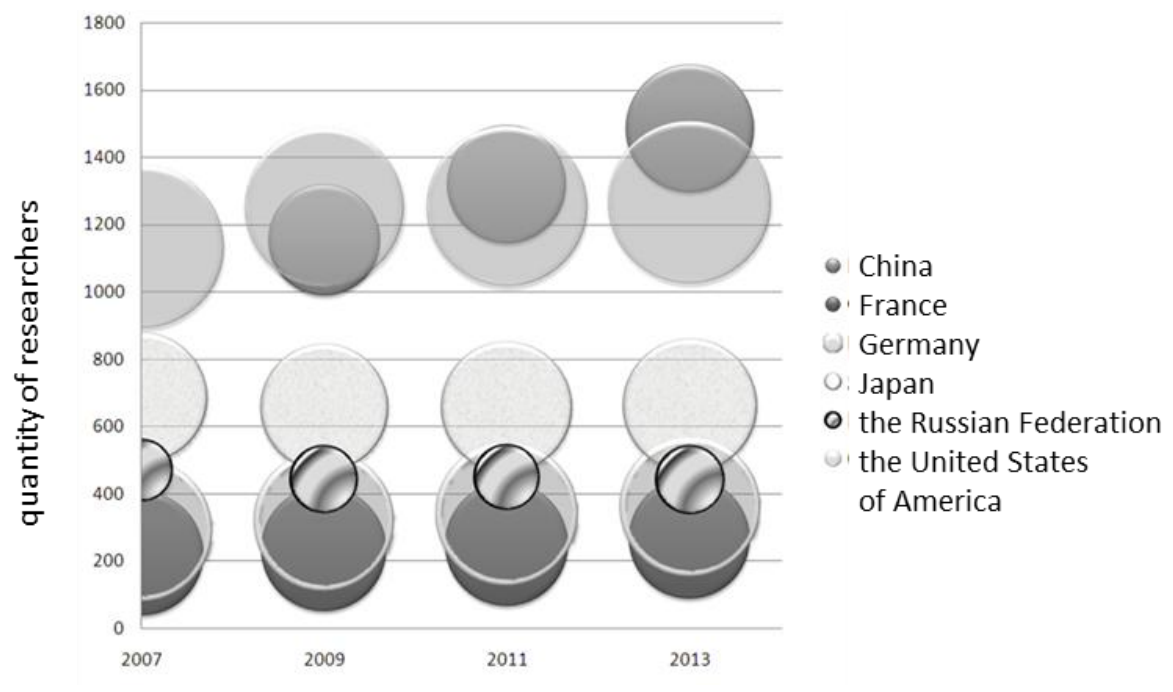

Figure 5 - R\&D expenditures change per one researcher (Source: UNESCO, 2015)

Low-income countries and countries with the income lower than average are categorised as peripheral countries or periphery, whereas high-income countries and countries with income higher than average are categorized as central or centre.

A negligible contribution (into innovative economic development, see Figures 5 and 6) of low-income countries in comparison with high-income countries and countries with income higher than average, is explained by the fact that capital renewal in weak countries is very slow. Thus, capital surplus (investments) is transferred to other countries that have more favourable conditions for capital development.

Knowledge economy externalities institutionally connected in space give an advantage to enterprises located in close proximity to knowledge sources in comparison with competing enterprises distant from these sources (Breshi \& Lissoni, 2012). Despite the fact that international knowledge market is an extensive system of relations between knowledge producers and consumers and a complex mechanism for coordinating interests, in the end, the leading countries tend to impose their own game rules alongside with national markets' demands for transparency.

Globally, there is a tendency to strengthen the role of the state in intellectual potential development through the mechanisms stimulating innovation economy and budget spending for social purposes.

Knowledge flows and brain migration together with widespread use of IT and infrastructure as well as institutional support for the innovation process "from knowledge into practice" are the most important components for both innovative and economic development of any country with an ambition to join the list of the leading economies.

Research skills greatly depend on innovative economy development. The most important feature of this type of economy is that human intellect is replacing manual labour. The focus is on shifting to such activities as data processing, analysing and interpreting.

It would be prudent to compare the related strategies between the countries. In our example below, we are using data on different countries from the UNESCO Scientific Report. All these countries are implementing new economic strategies: China, France, 
Germany, Korean Republic, USA, Japan (see Fig. 6).

On top of that, Japan and the USA have both increased their patents' share as compared to publications (Fig. 7). Special economic zones aiming to boost scientific innovations do exist in Russia, the United Kingdom and Canada. In such a way, countries that manage to attract both scientists and finances into the field demonstrate the fastest progress.

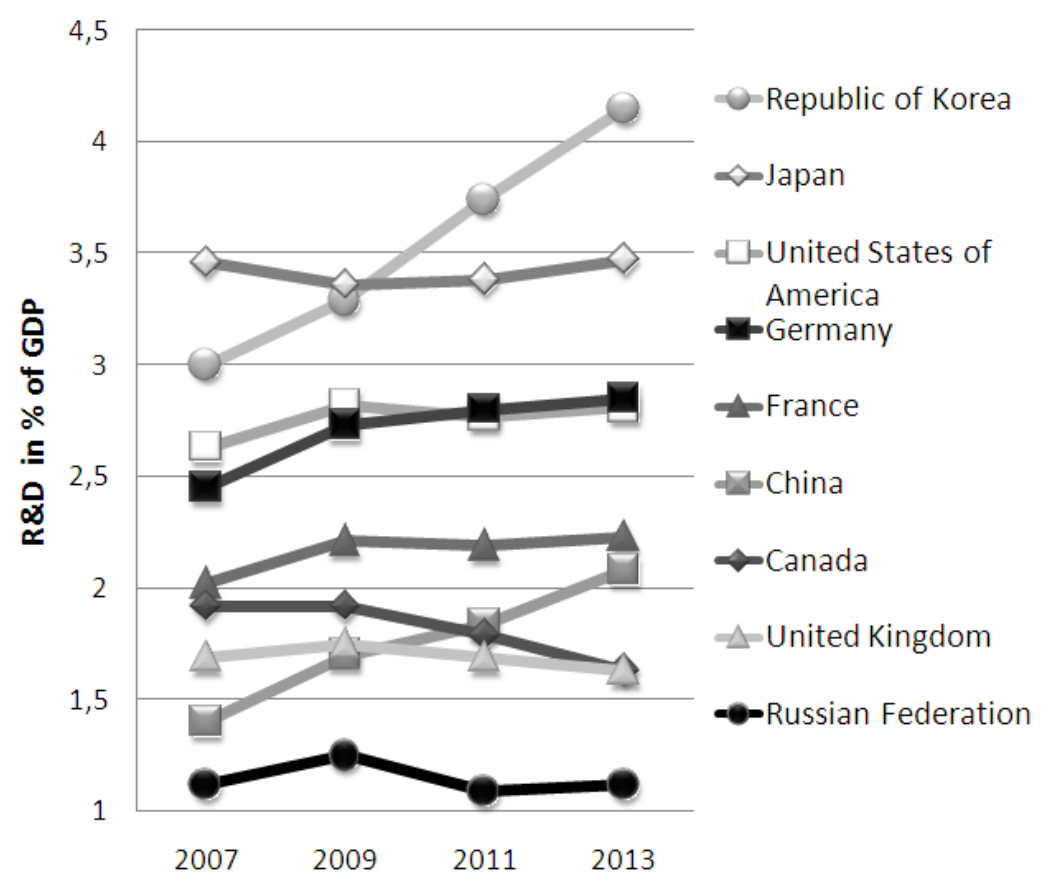

Figure 6 - R\&D dynamics in \% of GDP, 2007-2013

(Sources: UNESCO, 2015)

Today's communication technologies tend to increase information flows, positively affect people's movement and make researchers get much more easily connected online. At the same time, the latter trend is not yet significant for now. The UNESCO data shows that despite all the vast opportunities the Internet provides and availability of various online platforms in particular, brain physical migration is still the dominating global trend. After obtaining a doctorate degree, scientists often feel a need to change their location (UNESCO, 2015).

Recently, there has been some changes not only in terms of involvement degree, but also in quality of brain migration policies. This has been an attempt to provide response to a very serious problem -- researchers' downshifting and de-qualification.

According to the research done by N. Shmatko from the National Research University Higher School of Economics, the researchers' supply in the USA is significantly higher than its demand. Thus, annually about 36000 applicants apply for 3000 vacant working places at the academic market. In other words, this would be 12 people per 1 working place, and this leads to a really tough competition in the sector of the US university education (Shmatko et al., 2009). 73,6\% of the scientists who got their PhDs in the USA would like to stay in the country, a few exceptions being the nationals from Germany, France, and Scandinavian countries. 


\section{INTERNATIONAL HIGH-SKILLED PROFESSIONALS}

Among those who would like to stay are Chinese (90\%), Indians (86\%) and Central Eastern Europeans (83\%).

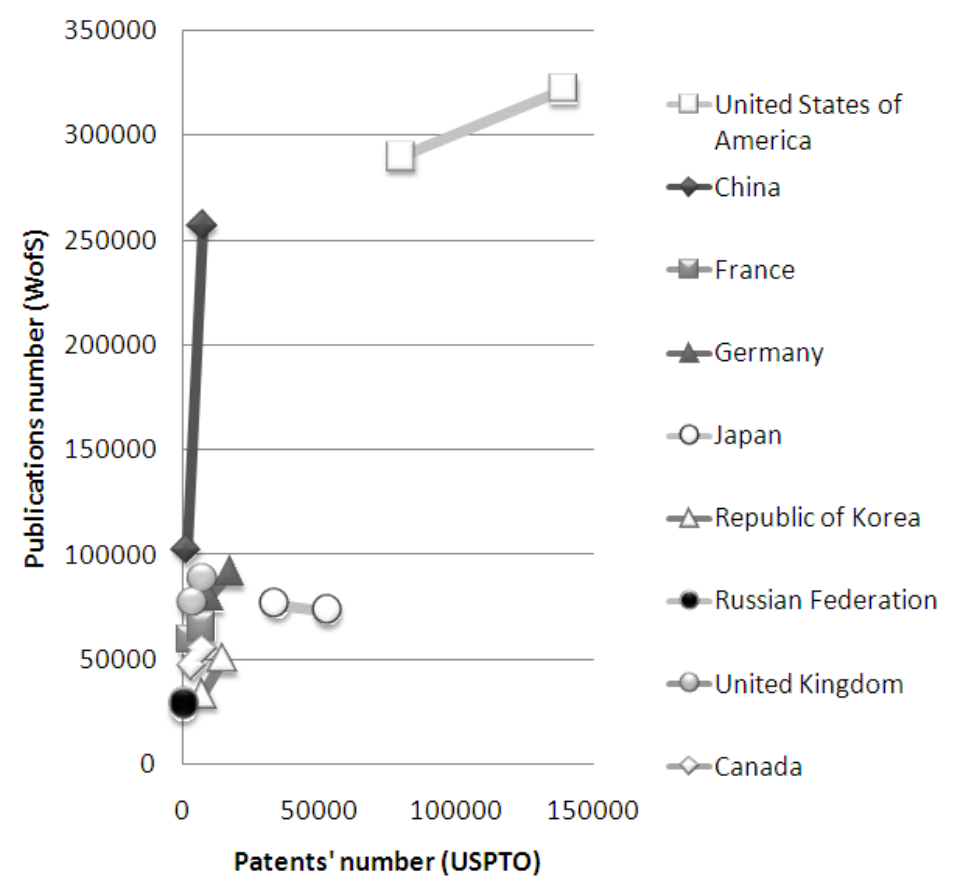

Figure 7 - Number of patents and publications

C. Franzoni conducted a comprehensive study on scientists' international mobility back in 2011. He noted that the most important motives for brain migration are: possibility for improving career prospects, a chance to join the research team with better scientific reputation, more options for international collaboration (Franzoni et al., 2012).

The most important professional incentives are better working conditions and more of career opportunities, financial benefits actually took the second place, while the third one belongs to moral incentives. At the same time, according to the interviewed researchers, the most effective measures for attracting young people to science are improved research funding and scientific infrastructure improvement (Ivancheva \& Gourova, 2011).

N. Shmatko also found that mobility distribution of scientists is subject to the Pareto law, though the trend also depends on a particular field of science in a country but not on individual features of scientists themselves (Shmatko, 2011). At the same time, there is also another trends observed: successful researchers born in Canada, France, Germany, Sweden, shortly after receiving their $\mathrm{PhD}$ and becoming "scientific elite" in the United States, still return to the country of their origin (Ascheulova \& Duschina, 2014).

Researchers' overproduction has also caused academic titles' devaluation. According to (Ascheulova \& Duschina, 2014), 17\% of all job posts in German universities and research centers are permanent positions, the rest are temporary positions only, while in American universities their share is about $50 \%$.

Both total unemployment rate and unemployment among doctors of science in Germany is higher than in the USA. Temporary status of many "postdoc" as well as availability of "extra people" at the academic market affect scientists" mobility, including intersectoral mobility. For example, in Belgium almost one third of those who have 
graduated have a job not related to their scientific major while in Poland their share is only 6\%, and in Russia even less -- 4.4\% (Schmatko, 2017, p. 41).

A. Krasteva points out that researchers who migrated to the EU are often employed in libraries, information centres and even when they get a "post-doc" placement, this would be a temporary position with a lower salary, and it might take some time before they get a permanent position of a professor or other permanent tenure at university (Krasteva, 2008).

The same situation is actually observed in many donor states as well. Bhagwati \& Dellalfar (1973) illustrated this situation on an example of a Philippino doctor who instead of starting medical practice in his own country, preferred working as a taxi driver until he got the opportunity to emigrate to the United States. These authors conclude that brain migration coming from developing countries entails significant losses for the economy as well as higher level of government spendings and a decrease in population well-being overall (Bhagwati, 1979). Wong \& Yip (1999) have built an empirical model in this regard. In it, economic growth was predetermined by human capital availability, thus, brain migration is obviously causing decreased economic growth.

We believe that decline in qualification standards happens all over the world because of the post-modern crisis, knowledge imitation and also growing popularity of pseudo-modern and pseudo-industrial surrogates. "Empty brands" are pushed to the frontline of scientific thought and innovative scientific and technologic progress for no reason (other than personal gain, of course).

We would like to offer a gravity model of brain migration developed on the data presented in the UNESCO Science Report 2030. This model is a so-called logical-semantic model which stems from the description of an object corresponding to all known and logically coherent statements and facts.

The gravity model of brain migration is a particular case of S. Stouffer's model in which a number of migrants moving on a certain distance is directly related to a number of emerging opportunities and inversely related to a number of intervening opportunities.

According to Stouffer's gravity model of migration (1940), brain migration shall be proportional to human resources' production in a donor state and human resources' consumption in a recipient state taking into account all emerging opportunities. It shall be also inversely proportional to movement costs and other costs related to a number of intervening opportunities (including those with institutional and social roots).

Not only the intensity of brain migration depends on a traditional migration factor, but also a systemic impact of other factors is taken into account in the given model. Unlike lowqualified employees, researchers are better at grasping opening opportunities connected with strategic consequences of systemic global changes.

Therefore, a common trend (presented in Fig.8 as the variables of "R\&D expenditure" and "GDP per capita") for brain migration includes new phenomena, namely, geographical scientific reorientation.

For the last several years "transnational mobility" (when both staying at a donor state and a recipient state becomes equally comfortable) is becoming very popular in the context of brain migration. This trend is well supported by digital economy and information society development overall.

It has become quite evident for such countries as the USA, Russia, China and some of European countries as well that transferring to a new technological level will not be possible only by means of attracting intellectual workers from donor states. 


\section{INTERNATIONAL HIGH-SKILLED PROFESSIONALS}

Transboundary knowledge flows (including brain migration, scientific co-authorship and the right for joint inventions' ownership) depend strongly on the factors which have nothing to do with science, but can be easily explained from the standpoint of new geopolitics and neoinstitutional theory.

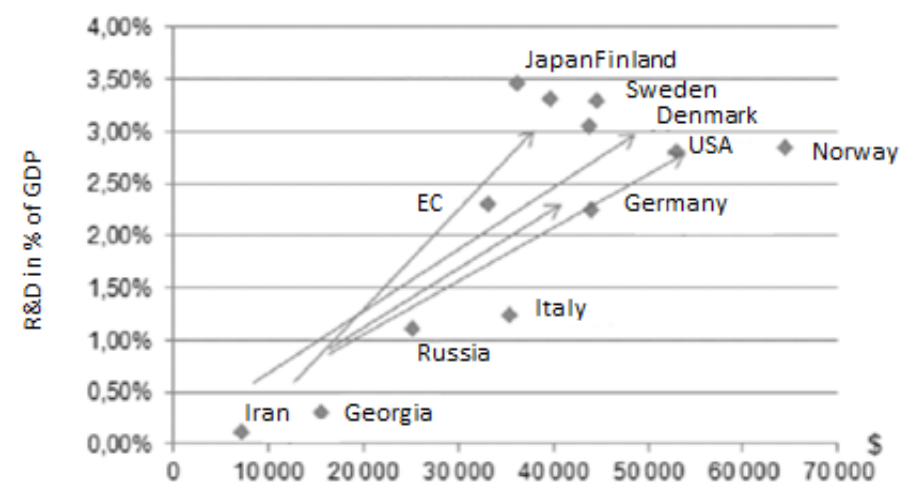

Figure 8 - Gravity model for brain migration, as of 2013

(authors' own modeling)

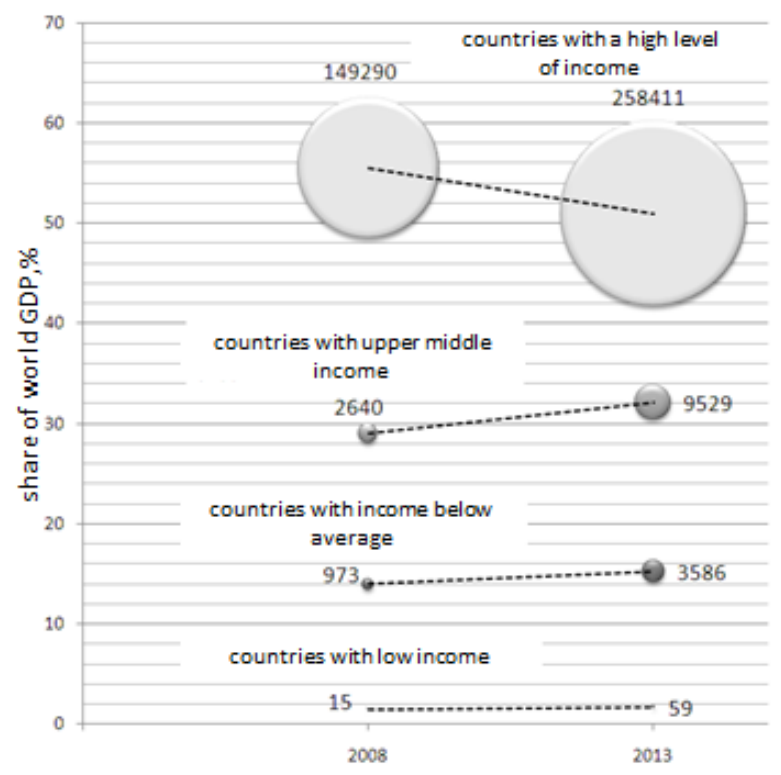

Figure 9 - Country groups' shares and their changes in the world GDP (in \%) as per the number of patents, as of 2008 and 2013

(Sources: UNESCO, 2015)

The suggested model reveals an increased concentration of economic indices and brain migration in the centre and lack of stimuli for developing innovations on the periphery. Fig. 10 clearly shows this. Developed countries, losing in GDP share, nevertheless, increase their superiority in innovations, on the one hand, changing economic structure, and on the other increasing dominance in legal field and concentrating on control over financial flows. 
Information and digital discrimination set by market institutions are directly coming from large conglomerates to the periphery (Tolstoguzov, 2016).

The agglomeration trend is being observed not only in the selected states.

In case we build 2 development axes "North-South" and "West- East" in Russian space, a clear picture would emerge: a developed innovation center and a lagging behind periphery. The similarity principle would be manifested for every macroregion: a developed center is fully engaged in innovations and then there is a periphery. The geography thus demonstrates the center's absolute leadership in the field of applied scientific products' creation. Let us consider this situation further on the example of the North-West Federal District. More than half of this district's production capacity is concentrated in St. Petersburg and the Leningrad Region. The presence of a large production and investment potential allows developing not only traditional, but also new types of activity, creating artificial competitive advantages taking into account the existing industrial basis.

Thus, the comparative analysis of enterprises innovative activities index from 2010 till 2013 shows the trend of increasing "innovativeness" in St. Petersburg agglomeration, which is both industrial and innovative centre of the Russian North-Western part, at the same time it also shows the periphery's disadvantage in terms of innovativeness (Tolstoguzov, 2016). The ratio between patents' quantity for inventions/useful models and researchers' quantity supports the concentration of innovative activities mainly in the centre (Tab. 2).

Table 2 - Population quantity, researchers' quantity and patents issued in the Russian North-West, as of 2013

(Sources: Federal State Statistics Service (Rosstat))

\begin{tabular}{|l|c|c|c|}
\hline & $\begin{array}{c}\text { Population, } \\
\text { ths people }\end{array}$ & $\begin{array}{c}\text { Researchers, } \\
\text { persons }\end{array}$ & $\begin{array}{c}\text { Patents for inventions and useful } \\
\text { models (2010-2013), units }\end{array}$ \\
\hline St. Petersburg (centre) & 5,132 & 78,773 & 11,330 \\
\hline $\begin{array}{l}\text { Other regions of the } \\
\text { Russian North-West } \\
\text { (periphery) }\end{array}$ & 8,625 & 16,901 & 2,894 \\
\hline
\end{tabular}

\section{Geographical Invariant Traits for Innovation}

Once again, the geography for innovative activity usually has the following, rather typical structure: a developed innovation centre and a backward periphery (in economic and innovative aspects).

Economic processes in this context are predetermined by coordination of subjects' activities as well as by the selected technological, social and historical factors. According to the neo-institutional theory agents' interactions in their various forms take place under the influence of quite definitive institutional factors which set the rules. In order to change economic reality, it is necessary to change institutional structures in the first place. The latter, in their turn, influence communication means and information exchange. As a result, agents' actions lead to economic exchanges and economic results are synchronised through the correct stimulus system.

The main issue here is to understand the actual reasons behind economy's development which occurs primarily due to industrial markets' increased profits and their spatial 


\section{INTERNATIONAL HIGH-SKILLED PROFESSIONALS}

distribution.

The first part of the problem is explained by organisation models as well as by industry markets' structure (international and interregional ones) which, in their turn, depend on labour social division and productive forces' distribution.

The second part of the problem can be explained by the factors influencing innovations development and increased profits' distribution caused by these innovations as well as by their spatial implementation. By means of applying innovations, a country or a region can receive a significant economic rent, and economic efficiency of the latter will be determined not only by its size, but also by its distribution. Innovations are the key source of artificial competitive advantage and thus, of the rent as well. They appear due to knowledge commercialization and the process of "theory into practice" implementation.

We also need to describe here the main properties of the innovative activities' geographical invariant within the neo-institutional approach. Firstly, there is a structural change in the world knowledge production system: the smallest relative growth in R\&D financing was performed by the cluster of the countries with high income levels, and the largest - by the countries with income levels above average - from $16.1 \%$ to $25.8 \%$. This indicates there is a growing attention to knowledge economy in this group of countries since for them the link between the contribution to world GDP and R\&D as well as exports increase due to high-tech development and knowledge-intensive industries is obvious.

Nowadays there are $7.76 \mathrm{mln}$ researchers all over the world (an increase in 2013 compared with 2007 was $21 \%$ ).

Most researchers are concentrated in the EU, China and the United States. In Russia there are 4406000 of researchers (as of 2013), their global share has decreased from $7.3 \%$ to $5.7 \%$ (UNESCO, 2015). The performance of academic degree holders is usually estimated through their publication and patent activity.

According to the UNESCO (2015), the global share of scientific publications has increased by $28 \%$ as compared to 2008. In $20141.27 \mathrm{mln}$ articles were published, in 2013 there were 277800 of patents (the leaders in both these categories are the US and the EU).

The UNESCO report claims that developed countries have shifted their focus from problem-oriented investigations to applied sciences' financing. Unfortunately, due to resources' insufficiency and overall low qualifications, the periphery cannot provide informational and legal support alongside the whole chain "from theory to practice" and thus is forced to choose the "turnkey portfolio" of innovative products. Comparing Fig. 10 and 11, how roles are changing in this regard.

The periphery creates more publications (according to Thomson Reuters Web of Science Citation Index Expanded) per researcher and per one dollar invested in R\&D, but at the same time these countries register much fewer patents per researcher and per one dollar of $R \& D$.

Despite the fact that international knowledge market is an extensive system of relations between producers and consumers and is a very complex mechanism for coordinating interests, in the end, leading states do impose their game rules requiring peripheral national markets to be more transparent and more open for international labor redistribution (Vinogradov \& Palmov, 2014). 


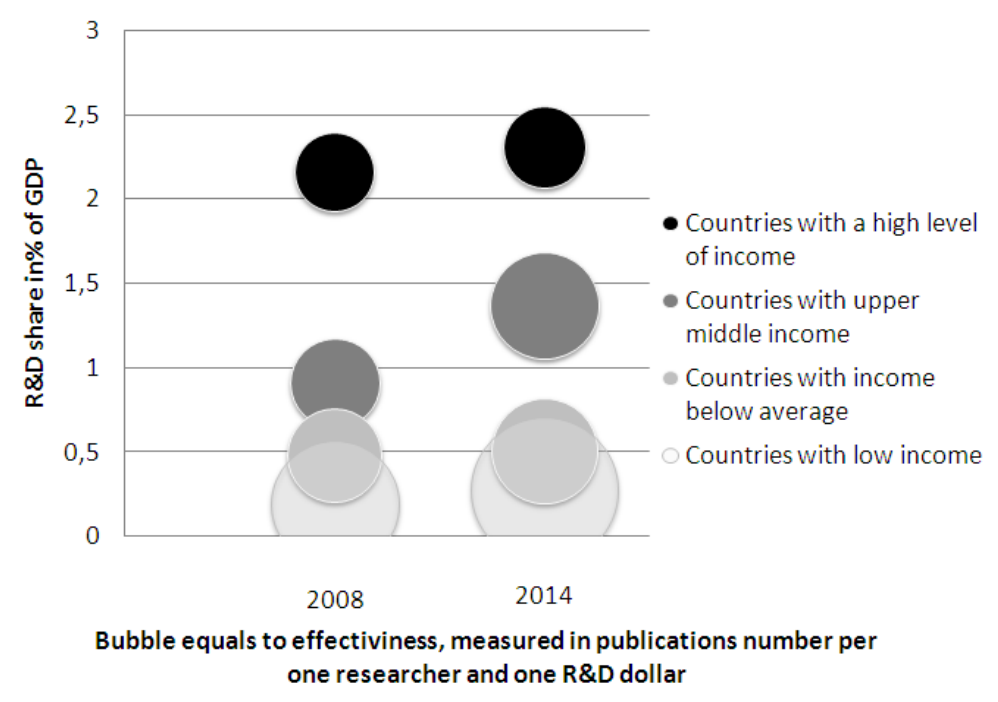

Figure 10 - Countries' innovation policy performance measured via publication activity (according to Thomson Reuters Web of Science Citation Index Expanded), per researcher and also per 1 USD spent on R\&D

(Sources: UNESCO, 2015)

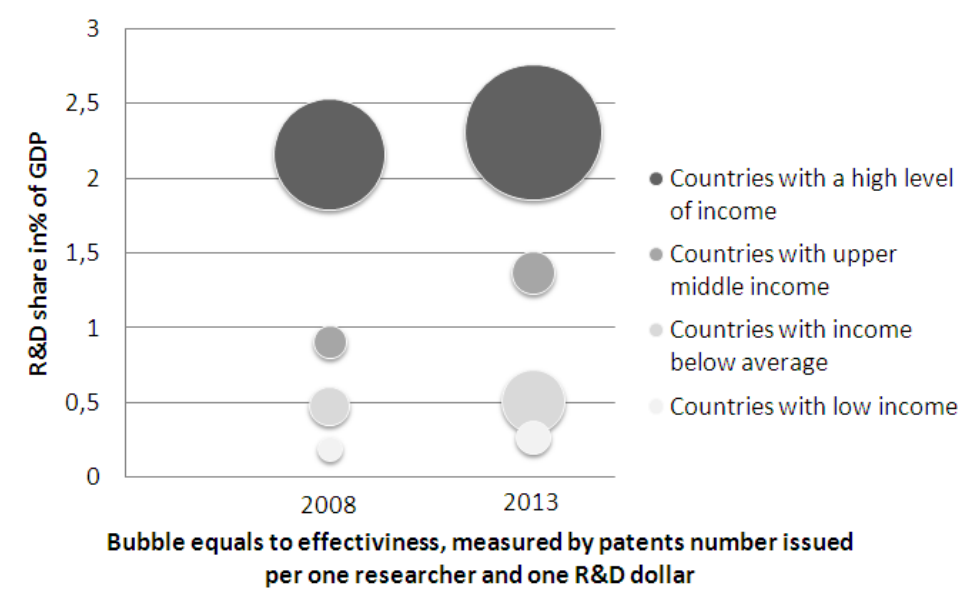

Figure 11- Countries' innovation policy performance measured via patents' quantity per one researcher and per 1 USD spent on R\&D

(Sources: UNESCO, 2015)

Relatively non-optimal relations in the chain "from theory to practice" and among its different subjects (author, employer, owner-licensee, licensor, investor) is predetermined mainly by the already settled economic order while current economic and institutional conditions in the centre and the periphery differ greatly. Large enterprises with huge market power (transnational corporations in the first place) are located in big agglomerations in highly innovatively developed countries. 


\section{INTERNATIONAL HIGH-SKILLED PROFESSIONALS}

This means that industry markets are imperfectly competitive. Therefore, behaviour of nearly all economic agents is predetermined to a greater degree by cooperative and noncooperative strategies of the biggest enterprises as well as by cartel agreements. The issue of taking advantages of new knowledge lies in innovative centre's dominance over the periphery. Due to market power resources concentration in the centre, the latter controls nearly all innovative processes.

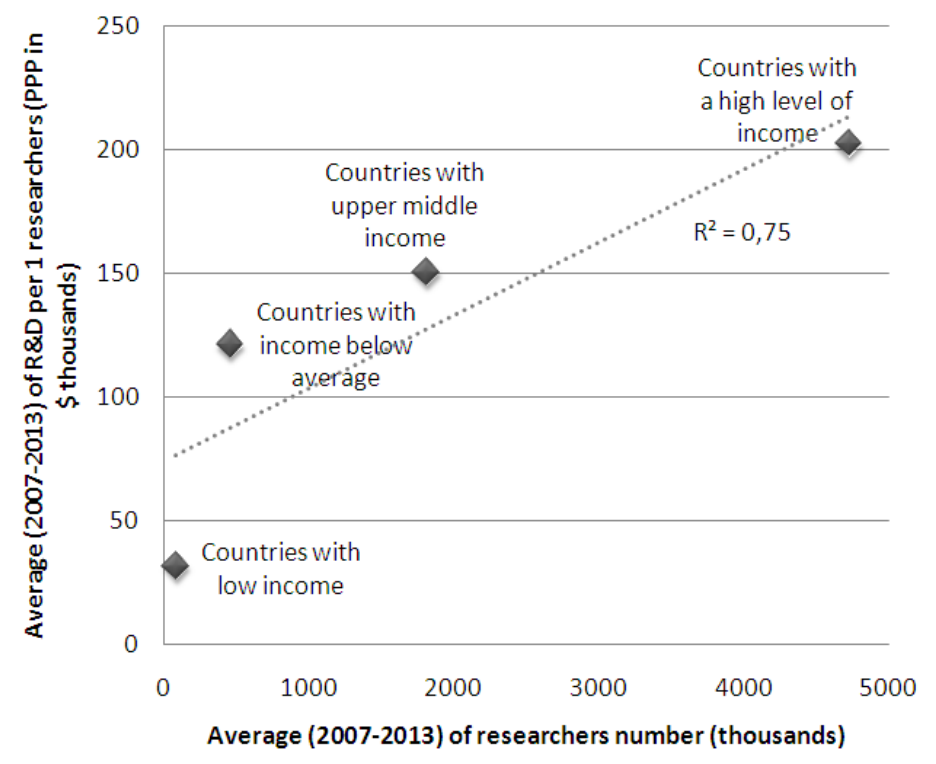

Figure 12 - The relationship between R\&D per 1 researcher (PPP in \$ thousands) and researchers' number (in thousands)

Secondly, both brain migration and intellectual workers' concentration depend on the conditions described above. Innovative activity is more intensive when this concentration is higher, since intellectual workers usually seek employment in fast developing companies and industries. If an industry is stagnating or declining, intellectual workers will do their best to relocate. Since fixed capital is substituted very slowly at the periphery, its surplus (the investment part) transfers to some other countries (where capital conditions are more attractive). And intellectual workers will always follow it. This relationship (with $\mathrm{R}^{2}=0,75$ ) is shown in Fig. 12.

Therefore, it is quite obvious that in order to ensure continuous and non-stop innovation process it is necessary to concentrate $\mathrm{R} \& \mathrm{D}$ activities and also increase the share of those involved in R\&D.

Thirdly, institutional maturity does matter, in particular, that of intellectual property and an appropriate contract system. A critical factor when it comes to innovations is the opportunistic behaviour of certain economic agents. This opportunism consists of deviating from the standard model; these deviations in the periphery are mainly caused by market power concentration (as compared to the centre) resulting in informal institutions' activity. This opportunism might be forced, it can be determined by external forces and it can contradict local community's joint interests. Still, the agreement cannot be broken and the agent must follow the discriminatory market relations. 
Undoubtedly, brain migration influences innovative economy development. It is innovations that lead to artificial competitive advantage and economic rent development; natural resources' presence or absence is of much less importance. Brain migration together with information \& communication technologies, innovative infrastructure (which eliminates digital discrimination and provides unified information space), institutional support for the formula "from theory into practice" are the most important constituents of innovative and economic development of all the countries in the world without any exceptions.

\section{Conclusion}

According to some of the forecasts, till 2030 high-tech industries will be growing economically, the share of spending on science in the USA will reach $3.1 \%$ of its GDP, in Japan $-3.5 \%$, in the EU $-2.1 \%$, in China $-2.3 \%$, in India $-2 \%$, and in Russia $-1.9 \%$ (the global spendings would be on average around $2.32 \%$ of the global GDP) (Strategic Global Forecast, 2013, p. 128).

While developing state policy oriented on innovative society development it is necessary to perform systemic work aimed at providing efficient decisions and coordinating all agents involved into the related process.

World trade and other institutions of the global level do require highly developed skills. Such skills would, in the first place, allow national legacy prioritizing over international one and at the same time not discriminating non-residents when it comes to intellectual property rights. Unfortunately, the periphery, due to its resources insufficiency and low qualifications overall, cannot provide informational and legal support along the whole chain "from theory into practice" and thus is forced to use only "turnkey" innovative products.

Alongside all positive influences from brain migration as described in the analysis above, there are also negative effects. Brain migration goes hand-in-hand with a destructive globalist influence characterized by true knowledge imitation in the form of pseudoindustrial surrogates and empty brands.

Strategically, brain migration is not the factor determining innovative policy success in this or that country. The much more important factor is the presence of scientific campuses in a country, availability of own research basis. Such knowledge reproduction is much more vital than importing scientific labour from other countries. It is the scientific campuses that prepare the country for transfer to a new technological level and could filter the surrogates hindering the development of real knowledge economy.

Innovative process is very unsatisfactory in the countries with poorly developed economics and low number of innovations. The inner demand for innovations can be the source for development in large agglomerations and innovative centres. However, the periphery needs an increased role of the state as the main customer and guarantor of innovations. Therefore, countries with insufficient level of innovations have to use administrative resources to accelerate their innovative development, but they should be very careful not to break any World Trade Organisation (WTO) regulations. The latter contain certain recommendations on how the states should support the generation and implementation of innovations.

All countries are facing the challenge of global innovation landscape. As this landscape is changing all the time, it requires systematic work on knowledge externalities' management, intellectual potential strengthening, brain migration regulation in order to 


\section{INTERNATIONAL HIGH-SKILLED PROFESSIONALS}

achieve a positive balance and form a truly knowledge economy as an integral part of country's industrial development.

Back in the 1960s-1970s already, the researchers T. Schulz (1961) and G. Becker (1975) noted the high role of education in human capital formation and that of the latter -- in economic development of the country. The negative effects in this regard arise due to changes in donor states' human capital quality. S. Di Maria and P. Stryszowski noted that migration prospects seriously limit motivations to increase agents' skills (Di Maria \& Stryszowski, 2009).

Due to market concentration, knowledge flows are mainly controlled by innovative leaders. Knowledge flows can be defined as "knowledge externals related in space" (Breschi $\&$ Lissoni, 2012, 163). To this understanding we might add a new clarification arising from economic space architectonics. Knowledge externals are mainly focused around financial flows' status-quo due to innovations' concentration in the center and consequent periphery's discrimination. In this case a good strategic solution for peripheral agents is their integration into the collective innovation processes initiated by them or the so-called global factories. This will provide favorable conditions for intellectual potential concentration, eventually turning into synergy effects for all.

Thus, the periphery states might actually achieve the goals of innovative competitive development as well as fair exchange in global trade but only through: economic mobilization; creation of own scientific campuses; elimination of discriminative institutions; improvement of own contract systems (according to international arbitrage practice); making sure there is coherence of trading rights and terms for both the centre and the periphery. It is also necessary to regulate brain migration through various state programmes aiming at brain migration development, for example, such programmes as "Global Education" in Russia.

\section{References:}

Alaev, E. B. (1983). Socioeconomic geography: conceptual and terminological dictionary. Moscow: Mysl'.

Almaev, M. H. et al. (2005). Knowledge economy and the factors of its implementation. Analytical Tribune, 15 (267), 64.

Arkhipov, A. \& Ushakov, D. (2018). Functional effectiveness and modern mechanisms for national urban systems globalization: The case of Russia. E-Planning and Collaboration: Concepts, Methodologies, Tools, and Applications, 3.

Ashcheulova, N.A. \& Dushina, S.A. (2014). Mobile science in the global world. Saint Petersburg: Nestor-Istoriya.

Becker, G. (1975). Human Capital.A theoretical and empirical analysis, with special reference to education. Available at: http://www.nber.org/chapters/c3730.pdf

Bhagwati, J. N. (1979). International Migration of the Highly Skilled: Economics, Ethics and Taxes. Third World Quarterly, 1 (3), 17-30.

Bhagwati, J. \& Dellalfar, M. (1973). The brain drain and income taxation. World Development, 1, 94-100.

Breshi, S. \& Lissoni, F. (2012). Localized flows of knowledge and the innovative environment: reconsidering the "implicitness" of knowledge. Smolensk: Ojkumena.

Di Maria, C. \& Stryszowski, P. (2009). Migration, human capital and economic development.Journal of Development Economics, 90, 306-313.

Franzoni, C., Scellato, G. \& Stephan, P. (2012). Foreign-born scientists: mobility patterns for 16 countries. Available at: http://www.nber.org/papers/w18067.pdf?new_window=1 
Ivancheva, L., Gourova, E. (2011). Challenges for career and mobility of researchers in Europe. Science and Public Policy, 38 (3), 185-198.

Krasteva, A. (2008). Immigration and integration: European experiences. Sofia: Manfred Worner Foundation.

Makarov, V.L. (2003). The economy of knowledge: lessons for Russia. Vestnik Rossijskoj akademii nauk, 73, 450.

Schultz, T. (1961). Investment in human capital. The American Economic Review, 51 (1), 1-17.

Shmatko, N., Suslov, A. et al. (2009). Mobility of research staff on national and international labor markets. Available at: http://econorus.org/onim/upload/knbc.pdf.

Shmatko, N.A. (2011). Research capital as the driver of social mobility of scientists. Foresight, 5(3), 18-32.

Shmatko, N.A. (2017). Mobility and career prospects of researchers on the labor market. Higher education in Russia, 1, 35-46.

Stouffer, S.F. (1940). Intervening Opportunities: A Theory Relating Mobility and Distance. The American Sociological Review, 5(6), 846-847.

Tolstoguzov, O. (2016). Innovative activity in the regions of North-Western Russia under crisis conditions. Innovacii, 1, 85-92.

Tran Van, H., Tran Huu, A. \& Ushakov, D. (2018). Liberal reforms \& economic growth: Current issues and interrelations. Journal of International Studies, 10(4).

UNESCO (2015). Science Report. Towards 2030. Available at: http://www.unesco.org/new/fileadmin/MULTIMEDIA/HQ/SC/pdf/USR_final_interactive.p df

Vinogradov, B.A. \& Palmov, V.G. (2014). Defense industry and Russian universities. Saint Petersburg Polytechnic University Publishing House.

Wong, K. \& Yip, C.K. (1999). Education, economic growth and brain drain. Journal of Economic Dynamics and Control, 23, 699-726.

Paper submitted

Paper accepted for publishing

Paper published online
05 December 2019

19 February 2020

02 April 2020 